\title{
PENGARUH PEMIKIRAN IBN TAYMIYYAH DI DUNIA ISLAM
}

\author{
Abdul Basyit \\ abdulbasyit1971@gmail.com \\ (Dosen Fakultas Agama Islam, Universitas Muhammadiyah Tangerang)
}

\begin{abstract}
Abstrak:
Kekuatan pemikiran Ibn Taymiyyah.1) kritik keras terhadap metode ta'wîl.2) menyarankan untuk memahami ajaran agama dengan cara menerima pesannya dan meyakini apapun makna lahir yang tersirat di dalam teks agama. 3) ajaran agama memiliki keunggulan dalam menyongsong modernitas. Pengaruh pemikiran Ibn Taymiyyah dapat dicerminkan oleh seberapa besar ketokohan intelektual para pengikutnya. Madjid Fakhry menyebutkan dua pemikir besar di dunia Islam yang sangat dipengaruhi oleh Ibn Taymiyyah, yakni Ibn al-Qayyim al-Jawziyyah dan Muhammad ibn Abd al-Wahhab. Seluruh gerakan Islam yang menamakan diri sebagai gerakan Salafiyyah adalah merupakan buah dari perkembangan luas pengaruh pemikiran Ibn Taymiyyah. Bagi Nurcholis Madjid, pemikiran Ibn Taymiyyah menjadi sesuatu yang doktrinal bagi banyak sekali gerakan pembaruan Islam zaman modern, baik yang fundamentalistik maupun yang liberal.
\end{abstract}

Kata Kunci: Pemikiran, Ibn Taymiyyah, Islam.

\section{A. Pendahuluan}

Pada saat ajaran Islam memasuki periode perkembangan peradaban pasca pergumulan budaya dengan bangsa dan agama lain, ajaran Islam mulai dipahami dan diamalkan dengan spirit rasionalisme dan terjadi proses intelektualisasi doktrin Islam dalam wujud pemikiran Islam yang pada giliranya melahirkan produk berbagai ilmu keislaman. Terjadi pula perubahan fokus studi Islam, tidak lagi terpusat pada aktivitas menelaah dan memahami sumber ajaran secara langsung, melainkan beralih pada studi produk jadi ijtihad ulama, tafsir, hadis, kalam, fiqh dan tasawuf. Akibatnya, pemahaman dan pengamalan agama yang semula sederhana dan murni menjadi rumit dan kompleks serta terjadi polarisasi.

Komitmen dengan remangat
pembaruannya, lbn $\begin{array}{r}\text { Taimiyyah } \\ \text { membangun pemikiran-pemikirannya }\end{array}$
lewat elaborasi al-Qur'an dan al-Sunnah
sebagaimana terlihat dalam tulisan-
tulisannya yang demikian luas mencakup
berbagai bidang ilmu seperti tafsir, hadis,

fiqh, kalam, filsafat, mantiq, tasawuf. Lewat tulisan-tulisannya itu, dia mengkritik secara tajam pandangan maupun pengamalan umat Islam yang menurutnya sudah tidak sesuai dengan spirit Islam yang murni yakni ajaran Islam yang ada dalam al-Qur'an dan al-Sunnah.

\section{B. Pengaruh Pemikiran Ibn Taymiyyah di Dunia Islam}

Ada beberapa aspek yang dapat dipandang sebagai kekuatan pemikiran Ibn Taymiyyah. Pertama, kritik keras Ibn Taymiyyah terhadap metode ta'wîl telah memberikan gambaran yang jelas bahwa bagi Ibn Taymiyyah, agama Islam adalah apa yang telah disampaikan oleh Allah dan rasul-Nya dengan contoh implementasi sebagaimana terdapat di dalam Sunnah Rasulullah saw. Setiap tambahan atas fakta-fakta ini harus dipandang sebagai bid'ah. Salah satu faktor utama bagi meluasnya bid'ah ini adalah intervensi rasional yang bebas terhadap prinsipprinsip agama misalnya, melalui konsep 
ta'wîl, penafsiran metaforik atau simbolik atas teks agama (al-nash). Ketika intervensi itu dibiarkan, ia akan menjadi lepas kendali. ${ }^{1}$

Kedua, Ibn Taymiyyah menyarankan untuk memahami ajaran agama dengan cara menerima pesannya dan meyakini apapun makna lahir yang tersirat di dalam teks agama. Ibn Taymiyyah mengawali argumennya dengan prinsip bahwa Tuhan mengetahui kebenaran jauh lebih baik daripada manusia dan mengetahui secara jauh lebih baik mengenai cara untuk mengungkapkan kebenaran tersebut. Firman Ilahi di dalam Al-Qur'an harus dipahami persis seperti yang diungkapkan. Makna kata yang langsung terlintas di dalam pikiran harus dipandang sebagai indikasi pemahaman yang benar terhadap kata itu. Dalam konteks ini, Ibn Taymiyyah memberikan apresiasi terhadap jargon al-Syafi'i dalam bidang Ushul Fiqh bahwa kecepatan pemahaman merupakan tanda kebenaran. Yang bertentangan dengan prinsip ini adalah konsep ta'wîl para filsuf Muslim yang mengambil bentuk penafsiran yang jauh (al-tafsîr al-ba îd $)^{2}$

Ketiga, bentuk pemahaman Ibn Taymiyyah terhadap ajaran agama ini dipandang memiliki keunggulan tersendiri dalam menyongsong modernitas. Dalam konteks ini patut dikemukakan analisis Hodgson bahwa modernitas menjadi perkembangan dunia yang tidak dapat dihindarkan. Menurut Hodgson, sebelum kemunculan aktualnya di Eropa Barat, modernitas memiliki peluang yang sama untuk muncul di berbagai pusat budaya dunia selain Eropa, khususnya Cina dan dunia Islam. Pertanyaan mengapa modernitas tidak muncul di dunia Islam

\footnotetext{
${ }^{1}$ Nurcholis Madjid, Ibn Taymiyyah on Kalam and Falsafa (A Problem of Reason and Revelation in Islam), h. 230.

${ }^{2}$ Lihat, Nurcholis Madjid, Ibn Taymiyyah on Kalam and Falsafa (A Problem of Reason and Revelation in Islam), h. 231.
}

dijawab Hodgson dengan menyatakan salah satu penyebabnya adalah bahwa dunia Islam memusatkan investasi sumber daya dan intelektualnya terlalu besar pada sebuah kawasan terbatas aktifitas kehidupan. Pengerahan sumber daya itu mungkin saja dipandang perlu, namun tidak adanya diversifikasi investasi sumber daya telah membuat kaum Muslimin menjadi terbelakang dalam bidang-bidang yang diperlukan untuk membuat menuju modernitas. ${ }^{3}$ Kajian-kajian yang terlalu difokuskan pada argumen-argumen keagamaan seperti pada bidang hukum fiqh bukan hanya semakin memburamkan cukup banyak prinsip dan orientasi keagamaan, namun juga telah menghabiskan waktu dan tenaga. Dilihat melalui perspektif ini, reformasi Ibn Taymiyyah beberapa abad silam dapat dipandang sebagai sebuah kontribusi besar bagi kaum Muslim modern. Penekanan Ibn Taymiyyah terhadap ijtihad dan sikapnya yang anti taklid akan menghadirkan kembali kebesaran kesederhanaan ajaran agama Islam. $^{4}$

Pengaruh pemikiran Ibn Taymiyyah dapat dicerminkan oleh seberapa besar ketokohan intelektual para pengikutnya. Madjid Fakhry menyebutkan dua pemikir besar di dunia Islam yang sangat dipengaruhi oleh Ibn Taymiyyah, yakni Ibn al-Qayyim al-Jawziyyah dan Muhammad ibn Abd al-Wahhab. ${ }^{5}$ Ibn Qayyim al-Jawziyyah hidup sezaman dengan Ibn Taymiyyah dan bahkan menjadi muridnya yang setia. Diriwayatkan bahwa ketika Ibn Taymiyyah kembali dari Mesir ke Damaskus pada 712

${ }^{3}$ Marshal G. Hodgson, The Venture of Islam, vol. 3 , h. 182.

${ }^{4}$ Lihat, Nurcholis Madjid, Ibn Taymiyyah on Kalam and Falsafa (A Problem of Reason and Revelation in Islam), h. 233.

${ }^{5}$ Madjid Fakhry, A History of Islamic Philosophy, (New York: Columbia Press, 2994), h. 329. 
H/1313 M, Ibn al-Qayyim yang saat itu masih berusia 21 tahun langsung menjadi murid Ibn Taymiyyah dan tetap bersamanya hingga Ibn Taymiyyah wafat pada 1328 M. Pada 1318 M, sultan melarang Ibn Taymiyyah menyampaikan fatwa tentang talak yang bertentangan dengan doktrin mazhab Hanbali yang sudah ada. Ibn Taymiyyah dijebloskan ke dalam penjara selama lima tahun namun masih diizinkan menerima kunjungan maupun menulis atau menyampaikan fatwa. Hanya setelah penahanannya pada $1326 \mathrm{M}$, yang dipicu oleh risalah kritisnya mengenai ziarah kubur, Ibn Taymiyyah akhirnya kehilangan kesempatan untuk menulis hingga akhirnya wafat pada 1328 M. Pada periode ini, Ibn al-Qayyim juga ditahan di penjara Damaskus karena dituduh melarang berziarah ke makam Nabi Ibrahim as. Ibn Hajar al-Asqalani meriwayatkan bahwa Ibn Qayyim alJawziyyah pernah ditahan bersama Ibn Taymiyyah di penjara setelah sebelumnya dia dinistakan dan diarak keliling kota di atas seekor unta. ${ }^{6}$ Karya Ibn Qayyim alJawziyyah umumnya membahas isu-isu teologis dalam Islam pada masanya. Dalam karyanya, Al-Shawâ'iq al-Mursalah 'ala al-Jahmiyyah wa-al-Mu'aththilah, Ibn Qayyim al-Jawziyyah merumuskan berbagai kritera tentang penyimpanganpenyimpangan besar (ushûl al-inhirâfât) kaum Jahmiyyah dan banyak sekte (alfiraq) lainnya. Menurut Ibn al-Qayyim, yang menambah buruk keadaan kaum Muslimin pada masanya antara lain adalah bahwa akal ('aql), hawa nafsu (alsyahwah), pendapat pribadi (al-ra'y), rasa

\footnotetext{
${ }^{6}$ Shihâb al-D|n Ahmad Ibn Hajar al'Asqalân|, Al-Durar al-Kâminah fî A 'yân al-Mi'ah al-Tsâminah, ed. Muhammad Rashid Jad al-Haqq, (Kairo, 1966-67), vol. 4, h.22.
}

pribadi (al-dzawq) sudah dipandang lebih utama daripada wahyu. ${ }^{7}$

Karya Ibn Qayyim lainnya yang cukup terkenal adalah Ijtimâ' al-Juyûsy alIslâmiyyah 'ala Ghazw al-Mu'aththilah wa-al-Jahmiyyah yang juga dikenal dengan judul al- 'Uluw wa al-Istiwâ' atau hanya al-Istiwâ'. Karya ini berisi kritik terhadap kaum Jahmiyyah dan membantah sekte yang meniadakan ( $t a$ 'thîl) sifat-sifat Tuhan. Ibn Qayyim membahas penjelasan dari ayat Al-Qur'an bahwa Tuhan duduk di atas 'arasy (al-Raḩmân 'ala al-'arsy istawâ). Judul risalah ini mengandung arti berkumpulnya tentara Islam untuk memerangi kaum Mu'aththilah dan kaum Jahmiyyah. Yang dimaksud oleh Ibn alQayyim dengan tentara Islam adalah ayatayat Al-Qur'an, sabda Rasulullah saw, pandangan para sahabat, tabi'in, para ulama ahli hadis dan para mufasir terkemuka. $^{8}$

Salah satu karya Ibn al-Qayyim yang juga populer di bidang ilmu tafsir adalah al-Tibyân fî̀ Îmân al-Qur'ân. Karya ini membahas metode penafsiran Al-Qur'an yang, seperti halnya Ibn Taymiyyah, menggunakan pendekatan tafsîr $b i$ alma'tsûr dan menafsirkan Al-Qur'an menurut Al-Qur'an (Bahwa ayat-ayat AlQur'an bersifat saling menjelaskan satu sama lain), Sunnah Rasulullah saw, pendapat para sahabat, pendapat kaum Salaf dan pendapat para ahli bahasa. Metode tafsir Ibn al-Qayyim ini sama persis dengan metode tafsir sang guru, Ibn Taymiyyah. Dalam karya ini, Ibn alQayyim menyatakan bahwa mengenai

\footnotetext{
${ }^{7}$ Ibn Qayyim al-Jawziyyah, Al-Shawâ'iq alMursalah 'ala al-Jahmiyyah wa-al-Mu'aththilah, Ed. 'Ali ibn Muh"ammad al-Dakhil Allah, (Riyadh, 1412/1991-92), vol. 1, h.15.

${ }^{8}$ Ibn Qayyim al-Jawziyyah, Ijtimâ' al-Juyûsy al-Islâmiyyah 'ala Ghazw al-Mu'aththilah wa-alJahmiyyah: Wa-huwa al-Risâlah al-Musammâ bi al-Istiwâ'," ed. Ridwan Jami' Ridwan (Makkah dan Riyadh, 1415/1995), h.5-7.
} 
kebangkitan di hari kiamat, mayoritas umat manusia mengetahuinya melalui informasi dari para nabi meski ada sebagian kecil manusia yang mengetahuinya melalui kontemplasi (al-nazhar). ${ }^{9}$

Karya Ibn al-Qayyim lainnya di bidang teologi Islam (kalam) adalah Syifấ, al- 'Alîl fi Masâ'il Qadhâ' wa al-Qadar wa al-Hikmah wa al-Ta'lîl (Obat Penyakit Dalam Persoalan Qadha', Qadar, Filsafat dan Terapinya). Di dalam karya ini, argumen-argumen Ibn al-Qayyim diarahkan untuk menyerang gagasan fatalistik kaum Jabariyah dan konsep ftee will kaum Qadariyah. Persoalan teologis semacam ini, bagi Ibn al-Qayyim, bukan hanya merupakan kajian akademik saja namun juga berkaitan dengan keyakinan pribadinya terhadap tanggungjawab manusia atas perbuatannya, dengan konsep tentang kebebasan memilih sebagai syarat utamanya. Karena itu, dengan tegar Ibn alQayyim menghadapi berbagai tuduhan telah mengaburkan batas-batas antara kebaikan dan keburukan atau-lebih tepatnya - antara yang pasti dan tidak pasti serta antara yang halal dan yang haram. Menurut Ibn al-Qayyim, keyakinan fatalisme bertentangan dengan logika hukum Tuhan, diutusnya para rasul dan adanya surga dan neraka di hari kiamat. ${ }^{10}$ Hal serupa berlaku pula bagi paham free will ketika dihadapkan kepada kehendak Tuhan. Dalam kaitan ini penting pula dikemukakan bahwa para peneliti warisan budaya (al-turâts) Islam yang telah menggarisbawahi pentingnya metode autentik dalam memahami ajaran agama (al-manhaj al-shahîh fî fahm al-'aqîdah)

${ }^{9}$ Ibn Qayyim al-Jawziyyah, al-Tibyân fì Îmân al-Qur'ân, (Makkah: Dar Alam al-Fawa'id li al-Nasyr wa al-Tawzi', 1429 H), h.10.

${ }^{10}$ Ibn Qayyim al-Jawziyyah, Mukhtashar Syifâ' al- 'Alîl fi Masâ'il Qadhâ' wa al-Qadar wa al-Hikmah wa al-Ta'lîl, ed.Khalid ibn 'Abd alRahman al-'Akk, (Beirut, 1996),h. 5. dan menurut mereka terdapat di dalam karya-karya Ibn al-Qayyim. ${ }^{11}$

Tokoh spektakuler lainnya yang dipengaruhi oleh pemikiran Ibn Taymiyyah adalah Muhammad ibn Abd alWahab, pendiri Wahabisme. Muhammad ibn 'Abd Wahhab lahir di Uyaynah (Najd), wilayah Saudi Arabia bagian timur. ${ }^{12}$ Muhammad ibn 'Abd Wahhab belajar fiqh dan ilmu-ilmu agama Islam lainnya dari ayahnya yang merupakan seorang hakim (qâdhî). Kemudian dia merantau ke Hijaz dan belajar ilmu agama dari para ulama di Makkah dan Madinah. Setelah menyelesaikan pelajarannya di Madinah, dia merantau ke Basrah dan menetap di kota ini selama empat tahun. Selanjutnya dia pindah ke Baghdad dan di sana dia menikah dengan seorang wanita kaya. Setelah istrinya wafat, dia pindah ke Kurdistan, lalu ke Hamdan dan Isfahan. Di kota Isfahan dia belajar filsafat dan tasawuf. Setelah bertahun-tahun merantau, akhirnya dia kembali ke tempat kelahirannya, Najd. ${ }^{13}$ Muhammad ibn 'Abd al-Wahhab dengan gerakannya untuk memurnikan ajaran Islam, tidaklah berkeinginan mengubah ajaran Islam dengan penafsiran baru terhadap wahyu. Tetapi membawa misi untuk memberantas bid'ah, khufarat, dan takhyul yang masuk ke dalam ajaran Islam. Muhammad ibn 'Abd al-Wahhab bermaksud mengajak umat Islam agar kembali kepada ajaran Islam yang murni yakni ajaran Islam sebagaimana yang dianut dan dipraktekkan di zaman Nabi saw, sahabat serta tabiin, yaitu sampai abad ke-3 Hijrah. ${ }^{14}$

\footnotetext{
${ }^{11}$ Ibn Qayyim al-Jawziyyah, Mukhtashar Syifâ' al- 'Alîl fi Masâ'il Qadhâ' wa al-Qadar wa al- $\underline{H}$ ikmah wa al-Ta'lîl, h.5.

${ }^{12}$ A. Hanafi, Teologi Islam, (Jakarta: Pustaka al-Husna, 1980), h.149.

${ }^{13}$ Harun Nasution, Pembaharuan dalam Islam, (Jakarta: Bulan Bintang, 1975), h.23;

${ }^{14}$ Harun Nasution, Pembaharuan dalam Islam, h.24;
} 
Ada dua macam keberhasilan Muhammad ibn 'Abd al-Wahab dan pergerakannya. Pertama, membentuk sebuah simbiosis mutualisma dengan Muhammad ibn Saud yang kemudian berhasil mendirikan sebuah negara Islam periode awal yang diberi nama alMamlakah al-'Arabiyyah al-Su'ûdiyyah dan Muhammad ibn Sa'ud menjadi rajanya yang pertama. Kedua, Wahabisme menjadi mazhab resmi negara dan Muhammad ibn 'Abd al-Wahab memiliki dukungan politik yang sangat kuat untuk menyiarkan ajaranajarannya di seantero negeri.

Salah satu pengaruh pemikiran Ibn Taymiyyah dan muridnya, Ibn Qayyim alJawziyyah, yang menyebar luas di dunia Islam adalah konsep tawhîd al-ulûhiyyah, tawhî̀ al-rubûbiyyah dan tawhîd al-asmâ' wa al-shifât. Seluruh gerakan Islam yang menamakan diri sebagai gerakan Salafiyyah adalah merupakan buah dari perkembangan luas pengaruh pemikiran Ibn Taymiyyah dan Ibn Qayyim alJawziyyah. Tokoh-tokoh yang merupakan bagian dari pergerakan Salafiyyah ini antara lain adalah Jamal al-Din al-Afghani (1839-1897 M), Muhammad Abduh (18491905 M), Muhammad Rashid Rida (18651935 M), Hassan al-Banna (1906-1949 M) dan sebagainya. ${ }^{15}$ Pengaruh ini juga dapat dilihat dalam gerakan al-Mahdiyyah di Sudan, gerakan Sanusiyyah di Libya, gerakan Islah dan Tajdid di benua India, gerakan Salafiyyah di Indonesia dan tidak terkecuali di Malaysia. ${ }^{16}$

\footnotetext{
${ }^{15}$ Keterangan lanjut tentang pengaruh Ibn Qayyim al-Jawziyyah terhadap para tokoh ini, lihat Charles C. Adams (2000), Islam and Modernism in Egypt. London: Routledge, $2^{\text {nd }}$ ed., h. 202-204.

${ }^{16}$ Amal Fathullah Zarkasyi, "Konsep Tauhid Ibn Taymiyyah dan Pengaruhnya di Indonesia: Kajian Kes Terhadap Pengubalan Kurikulum Pengajian Akidah di Pondok Modern Darussalam Gontor Ponorogo". Disertasi Doktor Falsafah Usuluddin, (Kuala Lumpur: Akademi Pengajian Islam Universiti Malaya, 2005), h. 5.
}

Pengaruh pemikiran Ibn Taymiyyah terhadap Muhammad Abduh tercermin melalui seruan Muhammad Abduh untuk kembali kepada Al-Qur'an dan Sunnah, dan sikap anti taklid demi melepaskan diri dari kejumudan. Abduh ingin membebaskan Mesir berada dari kebodohan dan kemunduran selama berabad-abad. Dia ingin meruntuhkan paham berbagai mazhab yang kaku lalu masuk ke alam kebebasan berpikir agar dapat menyelaraskan keyakinan keagamaan dengan kebutuhan zaman modern. ${ }^{17}$ Muhammad Abduh menonjolkan paham Ibn Taymiyyah yang menyatakan bahwa ajaran Islam meliputi ibadah dan Muamalat. Menurut Abduh, ajaran Islam yang terdapat dalam alQur'an dan hadis mengenai ibadah bersifat tegas, jelas dan terperinci. Sedangkan ajaran-ajaran mengenai kehidupan sosial hanya mencakup prinsip-prinsip yang bersifat umum. Dan juga melihat bahwa ajaran yang terdapat dalam al-Qur'an dan hadis mengenai kemasyarakatan hanya sedikit jumlahnya. Abduh berpendapat bahwa semua itu dapat disesuaikan dengan tuntutan zaman. ${ }^{18}$

Pengaruh pemikiran Ibn Taymiyyah terlihat jelas pada cara Rasyid Ridha memahami Al-Qur'an sebagaimana yang terdapat di dalam karyanya Tafsîr alManâr. Rasyid Ridha mengutip pendapat Ibn Taymiyyah bahwa ada dua macam sumber perbedaan dalam penafsiran AlQur'an. Pertama, perbedaan yang bersumber pada teks agama (al-naql) saja. Kedua, perbedaan yang bersumber pada selain teks agama. Persoalan ini kemudian berkembang menjadi pertanyaanpertanyaan apakah teks agama (dalam hal

${ }^{17}$ G.H.A. Juyuboll, Kontroversi Hadis di Mesir (1890-1960), alih basa: Ilyas Hasan, Cet. I, (Bandung: Mizan, 1999), h. 27.

${ }^{18}$ Harun Nasution, Pembaharuan Dalam Islam, Sejarah Pemikiran dan Gerakan, Cet. XIV. (Jakarta: Bulan Bintang, 2003), h. 54. 
ini selain Al-Qur'an) yang diriwayatkan itu berasal dari orang yang terpelihara dari dosa ataukah bukan. Kemudian apakah yang diriwayatkan itu mungkin diketahui kesahihannya ataukah tidak. Bagian yang tidak mungkin diketahui kesahihannya karena kelemahannya adalah apa yang secara umum tidak ada faedahnya bagi kita untuk mengetahuinya. Misalnya perbedaan pendapat di kalangan para mufasir mengenai apa nama dan warna anjing para penghuni goa (Ashhâhb al-Kahfi) atau bagian tubuh mana dari sapi yang dipukulkan kepada orang yang terbunuh, berapa berat kayu perahu Nabi Nuh as, atau nama anak kecil yang dibunuh oleh Nabi Khidr as, dan sebagainya.

Menurut Rasyid Ridha, yang mengutip dari Ibn Taymiyyah, jalan untuk mengetahui hal ini hanya bersumber pada teks agama (al-naql) yang dalam hal ini berupa hadis Nabi Muhammad saw. Jika memang hadis tersebut sahih diriwayatkan dari Nabi saw, tentu harus diterima. Tetapi jika yang diriwayatkan bersumber dari Ahl al-Kitab seperti Ka'ab dan Wahab, maka tidak boleh diambil keputusan untuk mempercayainya atau mendustakannya. Sebab ada hadis dari Nabi saw, "Jika Ahl al-Kitab menyampaikan sesuatu kepada kalian, maka janganlah kalian mempercayai mereka atau mendustakan mereka."19

Pemikiran Muhammad Rasyid Ridha juga dilihat melalui perspektif tasawuf dan Islam modern. Tren Salafi pada masa Muhammad Rasyid Ridha berada dalam dua aspek yang komplementer. Pertama, peneguhan kembali terhadap sekumpulan ajaran sederhana yang dianggap sebagai ajaran al-Salaf al-Shâlih. Kedua, perumusan kembali hukum dan moralitas sosial menurut kebutuhan masyarakat modern yang dilaksanakan dengan hati-

\footnotetext{
${ }^{19}$ Muhammad Rasyid Ridha, Tafsîr alManâr, (Kairo: Dar al-Manar, 1947), h.8.
}

hati dan dengan memperluas prinsip istishlâh (kemaslahatan umum). Di dalam kedua aspek tersebut, proses ini mencakup penolakan terhadap banyak keyakinan dan praktik Islam yang berkembang kemudian, dan utamanya keyakinan dan kegiatan yang ada di kalangan kaum sufi. Sebuah momen simbolik penolakan telah dijelaskan oleh Muhammad Rasyid Ridha, juru bicara gerakan Salafi pada generasinya. Muhammad Rasyid Ridha suatu ketika pernah menuturkan bahwa dia diajak oleh teman-temannya untuk menghadiri pertemuan para pengikut tarekat Mawlawiyyah di majelis mereka.

Majelis itu seperti sebuah tempat di surga di tepian sungai Abu Ali. Muhammad Rasyid Ridha memenuhi ajakan teman-temannya itu dan berangkat selepas salat Jumat. Pertemuan ini merupakan sesi pembuka bagi serangkaian pertemuan yang akan diadakan selama musim semi. Ketika sesi pertemuan dimulai, muncul para penari Mawlawi di depan hadirin dan guru mereka duduk di kursi kehormatan. Para penari itu adalah anak-anak muda tampan yang berpakaian putih laksana salju dan berpakaian laksana pengantin. Mereka menari memutar diiringi musik. Jubah mereka membentuk lingkaran dengan jarak yang harmonis. Mereka kemudian berpaling seraya membungkuk ke arah guru mereka. Muhammad Rasyid Ridha langsung bertanya mengenai gerakan ini dan langsung memperoleh jawaban bahwa itulah praktik ritual tarekat yang diajarkan oleh Jalaluddin Rumi, penulis Matsnawi. Muhammad Rasyid Ridha kemudian merasa tidak dapat lagi menahan dirinya lalu diapun berdiri di tengah-tengah majelis itu. Dengan suara lantang Rasyid Ridha berkata, "Para hadirin sekalian, atau dapatkah aku menyebut kalian sebagai Muslim? Ini semua adalah perbuatan yang diharamkan. Tak seorang pun boleh menonton atau membiarkannya. Siapapun 
yang telah melakukan ini, firman Allah berlaku, "Mereka telah menjadi agama mereka sebagai permainan dan olok-olok." Muhammad Rasyid Ridha kemudian bergegas meninggalkan tempat itu. Ketika dia menoleh ke belakang, ada beberapa orang yang keluar juga. Tetapi sebagian besarnya tetap berada di tempat itu." 20

Cerita di atas dengan gamblang menjelaskan apa yang sebenarnya ditolak oleh Muhammad Rasyid Ridha. Adalah jelas bahwa dia, seperti halnya sang guru, Muhammad Abduh, tidak akan mencela tasawuf secara gebyah uyah. Keduanya telah merumuskan perbedaan antara tasawuf yang sahih dan tasawuf yang sesat. Sebagian tokoh sufi yang benar, misalnya al-Junayd, al-Anshari dan Ibn Qayyim alJawziyyah, tentu mereka pandang sebagai bersejalan dengan garis yang ditempuh oleh generasi al-Salaf al-Shâlih, dan Abduh memandang bahwa kewajiban penting seorang pembaharu Islam adalah membangkitkan kembali tasawuf yang benar itu. $^{21}$

Dengan kata lain, tasawuf yang benar memiliki kecenderungan kepada tasawuf kaum Hanbali yang menekankan AlQur'an dan amalan kaum Salaf. Laoust sendiri bahkan telah membuktikan bahwa Hanbalisme dan sufisme dapat dipandang memiliki sumber yang sama, yakni perenungan dan peneladanan terhadap Nabi saw dan para sahabatnya. Banyak tokoh terkenal yang bermazhab Hanbali juga seorang sufi dan serangan keras para tokoh bermazhab Hanbali itu terhadap sufisme, misalnya serangan Ibn Qayyim alJawziyyah, sebenarnya merupakan serangan terhadap praktik-praktik gelap tertentu dan biasanya diiringi pula oleh

${ }^{20}$ Albert Hourani, The Emergence of The Modern Middle East, (California: University of California Press, 1981), h. 90.

${ }^{21}$ Albert Hourani, The Emergence of The Modern Middle East, h. 91. serangan terhadap bid'ah. Di dalam pemikiran Ibn Taymiyyah, ada penerimaan terhadap ahwâl dan pengalaman ma'rifah sebagai suatu pengalaman yang memiliki nilai kebenaran. Tetapi ia hanya merupakan pengalaman hidup biasa yang tetap bersejalan dengan Al-Qur'an dan hadis dan sama sekali tidak berarti memberikan justifikasi terhadap spekulasi metafisik yang merusak perbedaan antara Tuhan dan manusia atau melemahkan prinsip-prinsip syariah. Makdisi telah membuktikan bahwa Ibn Taymiyyah pernah menerima jubah (khirqah) sufi dari Ibn Qudama, seorang tokoh dengan silsilah keturunan yang kuat dari Abd al-Qadir alJaylani, seorang sufi yang juga bermazhab Hanbali. $^{22}$

Pengaruh pemikiran Ibn Taymiyyah terhadap pemikiran Hamka dapat terjadi melalui dua jalur, yakni jalur tidak langsung dan jalur langsung. Jalur tidak langsung tercermin melalui pengaruh pemikiran Muhammad Abduh terhadap Hamka melalui Tafsir al-Manar dimana Tafsir al-Manar banyak dipengaruhi oleh pemikiran Ibn Taymiyyah. Jalur langsung tercermin melalui kemungkinan Hamka membaca langsung karya-karya Ibn Taymiyyah kemudian dipengaruhi olehnya.

Kuatnya pengaruh pemikiran Ibn Taymiyyah tercermin pada gagasan sekularisasi Nurcholish Madjid. Bagi Nurcholis Madjid, pemikiran Ibn Taymiyyah menjadi sesuatu yang doktrinal bagi banyak sekali gerakan pembaruan Islam zaman modern, baik yang fundamentalistik maupun yang liberal. Selain itu, kritik Ibn Taymiyyah terhadap Kalam dan Falsafah dilakukan dengan kompetensi keilmuan Islam yang helenistik (seperti yang dikutip dalam salah satu

${ }^{22}$ Albert Hourani, The Emergence of The Modern Middle East, h. 94. 
suratnya terhadap Muhammad Roem tertanggal 29 Maret 1983). ${ }^{23}$

Dapat pula dikatakan bahwa dalam urusan bernegara, sekularisasi dipandang sebagai pemisahan antara dunia dan akhirat. Sekularisasi memilih menyerahkan urusan kehidupan sosial dan politik kepada seseorang yang handal di bidangnya, tanpa terpengaruh oleh latar belakang agama apa yang dianutnya. Dalam bernegara, masyarakat terdiri dari berbagai agama dan keyakinan, yang tentunya membutuhkan sikap dan perilaku yang adil dari pemimpin. Nurcholis Madjid mendukung tesis Ibn Taymiyyah bahwa Muhammad bukanlah seorang imam, tetapi seorang utusan Tuhan. ${ }^{24}$ Pemikiran Nurcholis Madjid ini merujuk kepada pemikiran Ibn Taymiyyah yang menjelaskan perbedaan antara ketaatan kepada utusan Tuhan dan ketaatan pada imam. Menurut Ibn Taymiyyah, jika dikatakan bahwa Nabi ditaati karena beliau adalah seorang imam sebagai implikasi dari kerasulannya, gagasan demikian tidak penting. Sebab secara sederhana kerasulan beliau saja sudah cukup memberi beliau hak untuk ditaati. Hal ini berbeda dengan imam, sebab sesorang dapat menjadi imam karena posisinya sebagai pemimpin yang harus menjalankan kekuasaannya. Jika tidak demikian, tentu dia akan sama saja dengan ilmuwan atau agamawan biasa. $^{25}$

Berbeda dengan Hamka, Nurcholis Madjid dipastikan membaca langsung karya-karya Ibn Taymiyyah dan dipengaruhi olehnya. Hal ini tercermin oleh fakta bahwa disertasi Nurcholis

${ }^{23}$ Ahmad Gaus, Api Islam Nurcholish Madjid: Jalan Hidup Seorang Visioner. (Jakarta: PT. Kompas Media Nusantara, 2010), h. 147.

${ }^{24}$ Nurcholish Madjid. Islam Agama Kemanusiaan, (Jakarta: Paramadina, 1995), h. 17.

${ }^{25}$ Ibn Taymiyyah. Minhâj al-Sunnah fì Naqdh Kalâm al-Syî'ah wa al-Qaddariyyah, (Riyadh: Maktrabat al-Riyadh al-Haditsah, tt), vol.1, 22-23.
Madjid di Chicago University adalah membahas pemikiran Ibn Taymiyyah tentang kalam dan falsafah.

\section{Penutup}

Ada beberapa aspek yang dapat dipandang sebagai kekuatan pemikiran Ibn Taymiyyah.

1. kritik keras Ibn Taymiyyah terhadap metode ta'wîl telah memberikan gambaran yang jelas bahwa bagi Ibn Taymiyyah. agama Islam adalah apa yang telah disampaikan oleh Allah dan rasul-Nya dengan contoh implementasi sebagaimana terdapat di dalam Sunnah Rasulullah saw.

2. Ibn Taymiyyah menyarankan untuk memahami ajaran agama dengan cara menerima pesannya dan meyakini apapun makna lahir yang tersirat di dalam teks agama.

3. bentuk pemahaman Ibn Taymiyyah terhadap ajaran agama ini dipandang memiliki keunggulan tersendiri dalam menyongsong modernitas.

Pengaruh pemikiran Ibn Taymiyyah dapat dicerminkan oleh seberapa besar ketokohan intelektual para pengikutnya. Madjid Fakhry menyebutkan dua pemikir besar di dunia Islam yang sangat dipengaruhi oleh Ibn Taymiyyah, yakni Ibn al-Qayyim al-Jawziyyah dan Muhammad ibn Abd al-Wahhab.

Menurut Ibn al-Qayyim, yang menambah buruk keadaan kaum Muslimin pada masanya antara lain adalah bahwa akal ('aql), hawa nafsu (al-syahwah), pendapat pribadi (al-ra'y), rasa pribadi (aldzawq) sudah dipandang lebih utama daripada wahyu.

Tokoh spektakuler lainnya yang dipengaruhi oleh pemikiran Ibn Taymiyyah adalah Muhammad ibn Abd alWahab, pendiri Wahabisme.

Ada dua macam keberhasilan Muhammad ibn 'Abd al-Wahab dan 
pergerakannya. Pertama, membentuk sebuah simbiosis mutualisma dengan Muhammad ibn Saud yang kemudian berhasil mendirikan sebuah negara Islam periode awal yang diberi nama $a l$ Mamlakah al-'Arabiyyah al-Su'ûdiyyah dan Muhammad ibn Sa'ud menjadi rajanya yang pertama. Kedua, Wahabisme menjadi mazhab resmi negara dan Muhammad ibn 'Abd al-Wahab memiliki dukungan politik yang sangat kuat untuk menyiarkan ajaranajarannya di seantero negeri.

Seluruh gerakan Islam yang menamakan diri sebagai gerakan Salafiyyah adalah merupakan buah dari perkembangan luas pengaruh pemikiran Ibn Taymiyyah dan Ibn Qayyim alJawziyyah. Tokoh-tokoh yang merupakan bagian dari pergerakan Salafiyyah ini antara lain adalah Jamal al-Din al-Afghani (1839-1897 M), Muhammad Abduh (18491905 M), Muhammad Rashid Rida (18651935 M), Hassan al-Banna (1906-1949 M).

Bagi Nurcholis Madjid, pemikiran Ibn Taymiyyah menjadi sesuatu yang doktrinal bagi banyak sekali gerakan pembaruan Islam zaman modern, baik yang fundamentalistik maupun yang liberal. Selain itu, kritik Ibn Taymiyyah terhadap Kalam dan Falsafah dilakukan dengan kompetensi keilmuan Islam yang helenistik.

\section{DAFTAR PUSTAKA}

A. Hanafi, Teologi Islam, (Jakarta: Pustaka al-Husna, 1980).

Amal Fathullah Zarkasyi, "Konsep Tauhid Ibn Taymiyyah dan Pengaruhnya di Indonesia: Kajian Kes Terhadap Pengubalan Kurikulum Pengajian Akidah di Pondok Modern Darussalam Gontor Ponorogo". Disertasi Doktor Falsafah Usuluddin, (Kuala Lumpur: Akademi Pengajian Islam Universiti Malaya, 2005).
Albert Hourani, The Emergence of The Modern Middle East, (California: University of California Press, 1981).

Ahmad Gaus, Api Islam Nurcholish Madjid: Jalan Hidup Seorang Visioner. (Jakarta: PT. Kompas Media Nusantara, 2010).

G.H.A. Juyuboll, Kontroversi Hadis di Mesir (1890-1960), alih basa: Ilyas Hasan, Cet. I, (Bandung: Mizan, 1999).

Harun Nasution, Pembaharuan Dalam Islam, Sejarah Pemikiran dan Gerakan, Cet. XIV. (Jakarta: Bulan Bintang, 2003).

Harun Nasution, Pembaharuan dalam Islam, (Jakarta: Bulan Bintang, 1975)

Muhammad Rasyid Ridha, Tafsîr alManâr, (Kairo: Dar al-Manar, 1947).

Madjid Fakhry, A History of Islamic Philosophy, (New York: Columbia Press, 2994)

Nurcholish Madjid. Islam Agama Kemanusiaan, (Jakarta: Paramadina, 1995).

Ibn Qayyim al-Jawziyyah, Al-Shawâ'iq alMursalah 'ala al-Jahmiyyah wa-alMu'aththilah, Ed. 'Ali ibn Muh"ammad al-Dakhil Allah, (Riyadh, 1412/1991-92).

Ibn Qayyim al-Jawziyyah, Ijtimâ' alJuyûsy al-Islâmiyyah 'ala Ghazw alMu'aththilah wa-al-Jahmiyyah: Wahuwa al-Risâlah al-Musammâ bi alIstiwâ'," ed. Ridwan Jami“ Ridwan (Makkah dan Riyadh, 1415/1995).

Ibn Qayyim al-Jawziyyah, al-Tibyân fî Îmân al-Qur'ân, (Makkah: Dar Alam al-Fawa'id li al-Nasyr wa al-Tawzi', $1429 \mathrm{H})$

Ibn Qayyim al-Jawziyyah, Mukhtashar Syifâ' al- 'Alîl fi Masâ'il Qadhâ' wa al-Qadar wa al-Hikmah wa al-Ta 'lîl, ed.Khalid ibn 'Abd al-Rahman al'Akk, (Beirut, 1996) 
Shihâb al-Din Ahmad Ibn Hajar al'Asqalân|, Al-Durar al-Kâminah fî̀ A'yân al-Mi'ah al-Tsâminah, ed. Muhammad Rashid Jad al-Haqq, (Kairo, 1966-67) 
